\title{
Platelet Count before Peripheral Blood Stem Cell Mobilization Is Associated with the Need for Plerixafor But Not with the Collection Result
}

\author{
Marc-Andrea Baertsch ${ }^{a} \quad K^{2}$ atharina Kriegsmann ${ }^{a} \quad$ Petra Pavel $^{\mathrm{b}} \quad$ Thomas Bruckner $^{\mathrm{c}}$ \\ Michael Hundemer $^{\text {a }}$ Mark Kriegsmann ${ }^{d}$ Anthony D. Ho ${ }^{a}$ Hartmut Goldschmidt ${ }^{a, e}$ \\ Patrick Wuchter ${ }^{f}$ \\ a Department of Medicine V (Hematology, Oncology and Rheumatology), University Hospital Heidelberg, Heidelberg, Germany; \\ bStem Cell Laboratory, IKTZ Heidelberg GmbH, Heidelberg, Germany; \\ ${ }^{c}$ Institute of Medical Biometry und Informatics, Heidelberg University, Heidelberg, Germany; \\ ${ }^{d}$ Institute of Pathology, Heidelberg University, Heidelberg, Germany; \\ e National Center for Tumor Diseases, Heidelberg University Hospital, Heidelberg, Germany; \\ ${ }^{f}$ Institute of Transfusion Medicine and Immunology, Medical Faculty Mannheim, Heidelberg University, \\ German Red Cross Blood Service Baden-Württemberg - Hesse, Mannheim, Germany
}

\section{Keywords}

Peripheral blood stem cell mobilization .

Poor mobilization · Platelet count · Plerixafor

\section{Summary}

Background: A low platelet count before mobilization has recurrently been identified as risk factor for poor mobilization. Methods: To determine the relevance of this finding for peripheral blood stem cell (PBSC) mobilization, including pre-emptive or rescue plerixafor in the case of poor mobilization, we retrospectively analyzed all patients undergoing PBSC collection at our institution between January 2014 and December $2015(n=380)$. Results: In total, $99 \%$ of the patients (377/380) successfully collected a minimum of $2 \times 10^{6} \mathrm{CD} 34+$ cells $/ \mathrm{kg}$ body weight sufficient for a single transplant. Rescue or preemptive plerixafor was administered to $11 \%$ of the patients (42/380). No correlations between the platelet count before mobilization and the number of peripheral blood CD34+ cells or the CD34+ cell collection result were detected in the entire population or the subgroups according to diagnosis (newly diagnosed multiple myeloma, relapsed multiple myeloma, lymphoma, amyloid light-chain amyloidosis, sarcoma, or germ cell tumor). However, patients requiring pre-emptive or rescue

Marc-Andrea Baertsch and Katharina Kriegsmann contributed equally to this work. plerixafor had a significantly lower platelet count before mobilization $(217 / \mathrm{nl}$ vs. $245 / \mathrm{nl} ; \mathrm{p}=0.004)$. Conclusion: With the current state of the art PBSC mobilization strategies, the platelet count before mobilization was not associated with the CD34+ cell collection result but was associated with the need for pre-emptive or rescue application of plerixafor.

(c) 2017 S. Karger GmbH, Freiburg

\section{Introduction}

Autologous blood stem cell transplantation (ABSCT) after highdose chemotherapy (HDCT) is a standard treatment for multiple myeloma (MM) [1] and lymphoma [2-4]. Less frequently, a range of other disease entities, including amyloid light-chain (AL) amyloidosis, sarcoma, germ cell tumors and autoimmune diseases, are treated with HDCT/ABSCT [5].

Regimens for mobilization of peripheral blood stem cells (PBSCs) for ABSCT differ according to the disease entity. The following two basic principles are common practice: i) for chemotherapy mobilization, the patient receives a cycle of mobilizationspecific chemotherapy followed by repeated administration of granulocyte colony-stimulating factor (G-CSF) or G-CSF during the reconstitution phase after a cycle of disease-specific chemotherapy or ii) for steady-state mobilization, only repeated adminis-

\section{KARGER}

(c) 2017 S. Karger GmbH, Freiburg

Fax +497614520714 
tration of G-CSF is performed [6]. Since its regulatory approval in 2008/2009, the CXCR4 inhibitor plerixafor can be administered to increase CD34+ cell yields in both approaches.[7] Due to its high cost, plerixafor is generally restricted to patients failing to reach sufficient peripheral blood (PB) CD34+ cell counts (pre-emptive use) or patients failing to collect sufficient CD34+ cells during leukapheresis (LP; rescue use) [8, 9].

Although PBSC mobilization and collection are highly effective in the majority of patients, poor mobilization has been reported in approximately $15 \%$ of the patients [10]. Risk factors for poor mobilization include prior chemotherapy (particularly alkylating agents), prior irradiation, low blood counts before mobilization, an extended interval between diagnosis and mobilization, and patient age $[6,10-14]$. The platelet count before mobilization (PCBM) has repeatedly been reported to be associated with mobilization and/or collection outcomes [12, 14-20]. Most of these reports originate from the pre-plerixafor era or the mobilization strategies did not incorporate plerixafor. Consequently, failure rates were considerably high.

In this report, we aimed to analyze the predictive value of the PCBM with CD34+ cell mobilization and collection results in a patient population that received mobilization regimens incorporating pre-emptive or rescue plerixafor in the case of poor mobilization.

\section{Patients and Methods}

\section{Patient Selection, Data Collection, and Matching}

All patients undergoing PBSC collection at the Department of Hematology, Oncology, and Rheumatology of the University Hospital Heidelberg between January 2014 and December 2015 were reviewed retrospectively. 17 patients were excluded from the analysis due to missing PCBM $(n=4)$ or rare indications (pancreatoblastoma $(n=1)$, ovarian cancer $(n=1)$, acute lymphatic leukemia $(n=1)$, T-cell lymphoblastic lymphoma $(n=2)$, acute myeloid leukemia $(\mathrm{n}=1)$, and autoimmune disorders $(\mathrm{n}=7))$. Overall, 380 patients were included.

Clinical and disease-related parameters (gender, age at diagnosis, disease status, previous number of therapy lines, age at PBSC collection, body weight, and disease duration until PBSC collection), blood counts before mobilization, mobilization regimens, plerixafor administration and PBSC collection parameters (PB CD34+ cell count, number of LP sessions, processed blood volume, and $\mathrm{CD} 34+$ cell collection result $/ \mathrm{kg}$ ) were extracted from the medical records. One line of therapy was defined as all therapeutic regimens applied without intercurrent progressive disease. For example, induction, mobilization, consolidation and maintenance treatment during first-line treatment was regarded as one line of therapy. The blood count before mobilization was determined during an outpatient visit typically one to two weeks before initiation of PBSC mobilization. Data were evaluated for the overall cohort and with regard to disease entity (MM, AL amyloidosis, lymphoma, sarcoma, and germ cell tumor), need for preemptive/rescue plerixafor and PB CD34+ cell count on day 1 of LP $\leq$ or $>20 / \mu l$.

For therapeutic procedures and anonymized data evaluation, patients' informed written consent was obtained. Retrospective data analysis was approved by the Ethics Committee of the Heidelberg University Medical Faculty (No. S-337/2009; S-078/2013) and meets the standards of the Declaration of Helsinki in its current version [21].

\section{Mobilization Regimens}

The following chemotherapy mobilization regimens were administered depending on disease entities: CAD (cyclophosphamide $1,000 \mathrm{mg} / \mathrm{m}^{2} /$ day day 1 , doxorubicin $15 \mathrm{mg} / \mathrm{m}^{2} /$ day days $1-4$, dexamethasone $40 \mathrm{mg} /$ day orally days 1-4), CD (cyclophosphamide 1,000 $\mathrm{mg} / \mathrm{m}^{2} /$ day day 1 , dexamethasone $40 \mathrm{mg}$ / day orally days $1-4)$, cyclophosphamide only $\left(1,000-2,000 \mathrm{mg} / \mathrm{m}^{2} /\right.$ day day 1$)$, (R-)CHOP (rituximab $375 \mathrm{mg} / \mathrm{m}^{2} /$ day day 0 , cyclophosphamide $750 \mathrm{mg} / \mathrm{m}^{2} /$ day day 1 , doxorubicin $50 \mathrm{mg} / \mathrm{m}^{2} /$ day day 1 , vincristine $1.4 \mathrm{mg} / \mathrm{m}^{2} /$ day - maximum $2.0 \mathrm{mg}$ - day 1 , prednisone $100 \mathrm{mg}$ /day days $1-5$ ), (R-)CHOEP (rituximab $375 \mathrm{mg} / \mathrm{m}^{2} /$ day day 0, CHOP plus etoposide $100 \mathrm{mg} / \mathrm{m}^{2} /$ day days $1-3$ ), (R-)DHAP (rituximab $375 \mathrm{mg} / \mathrm{m}^{2} /$ day day 0, dexamethasone $40 \mathrm{mg} /$ day days $1-4$, cisplatin $25 \mathrm{mg} / \mathrm{m}^{2} /$ day days $1-4$, cytarabine $2 \times 2,000 \mathrm{mg} / \mathrm{m}^{2} /$ day day 2 ), (R-)ICE (rituximab $375 \mathrm{mg} / \mathrm{m}^{2} /$ day day 0 , etoposide $100 \mathrm{mg} / \mathrm{m}^{2}$ days $1-3$, ifosfamide $5,000 \mathrm{mg} / \mathrm{m}^{2}$ day 2, carboplatin AUC 5, maximum $800 \mathrm{mg}$ day 2), (R-) AraC/TT (rituximab $375 \mathrm{mg} / \mathrm{m}^{2} /$ day day 0 , cytarabine $3,000 \mathrm{mg} / \mathrm{m}^{2} /$ day days 1 -2, thiotepa $40 \mathrm{mg} / \mathrm{m}^{2} /$ day day 2 ), VIDE (vincristine $1.5 \mathrm{mg} / \mathrm{m}^{2}$ day 1 , ifosfamide $3 \mathrm{~g} / \mathrm{m}^{2}$ days $1-3$, doxorubicin $20 \mathrm{mg} / \mathrm{m}^{2}$ days $1-3$, etoposide $150 \mathrm{mg} / \mathrm{m}^{2}$ days $1-3$ ), and PEI (cisplatin $20 \mathrm{mg} / \mathrm{m}^{2}$ on days $1-5$, etoposide $75 \mathrm{mg} / \mathrm{m}^{2}$ on days $1-5$, and ifosfamide $1,200 \mathrm{mg} / \mathrm{m}^{2}$ ).

G-CSF was administered daily $(5-10 \mu \mathrm{g} / \mathrm{kg}$ body weight (bw) subcutaneously) beginning from day 3 to 5 after completion of mobilization chemotherapy until the end of PBSC collection. From the 6 th day of G-CSF administration onwards, daily blood samples were drawn about $2 \mathrm{~h}$ after morning G-CSF dose.

In few individual patients, chemotherapy mobilization was avoided in favor of steady-state mobilization at the discretion of the treating physician, mainly due to comorbidities implying an increased risk of chemotherapy-associated complications. For steady-state mobilization, G-CSF $(10 \mu \mathrm{g} / \mathrm{kg}$ bw subcutaneously, split into two doses in the morning and evening) was initiated 5 days prior to the scheduled first day of LP.

In case of poor mobilization, pre-emptive or rescue mobilization with plerixafor was administered as described before in detail [8]. Briefly, after chemomobilization a plateau of $<10 \mathrm{CD} 34+$ cells/ $\mu \mathrm{l} \mathrm{PB}$ under continued G-CSF stimulation (i.e. leukocytes $>5 / \mathrm{nl}$, platelets $>100 / \mathrm{nl}$, and no increase of CD34+ cells in $\mathrm{PB}$ compared to the previous day) and after steady-state mobilization a CD34+ cell count of $<10 / \mu \mathrm{l}$ in $\mathrm{PB}$ at day 5 triggered pre-emptive application of plerixafor. Rescue mobilization with plerixafor was applied if less than onethird of the collection goal was reached with the first LP session. Between CD34+ cell levels of 10 and $20 / \mu \mathrm{l}$ in PB, plerixafor was used at the discretion of the treating physician with regard to the individual collection goal and comorbidity. Plerixafor $(240 \mu \mathrm{g} / \mathrm{kg})$ was administered subcutaneously 9-12 h before the LP session.

\section{CD34+ Cell Measurement and PBSC Collection}

When the $\mathrm{PB}$ white blood cell count $\left(\mathrm{WBC}\right.$ ) reached $\geq 5.0 \times 10^{3} / \mu \mathrm{l}$, the $\mathrm{PB}$ CD34+ cell count was determined by flow cytometry (FACS Calibur; Beckton Dickinson, New York, NY, USA) as previously described [9]. LP was initiated at a PB CD34+ cell count $\geq 20 / \mu$ l. In case of poor mobilization, pre-emptive or rescue application of plerixafor was initiated as described above. Hemoglobin levels of $\geq 8 \mathrm{~g} / \mathrm{dl}$ and platelet levels of $\geq 50 \times 10^{9} / 1$ were mandatory for LP initiation; erythrocytes and/or platelets were transfused immediately before or after LP if these levels were not reached; this did not interfere with the analysis of the predictive value of blood counts before mobilization, since transfusion in order to meet apheresis thresholds were performed after mobilization.

Stem cells were collected via peripheral or central venous catheters using a Spectra Optia ${ }^{\circledR}$ apheresis machine (software V7.2 and two-step tubing system or software V11.2 and cMNC (continuous mononuclear cell collection) tubing system) according to the manufacturers' instructions (TerumoBCT, Zaventem, Belgium) and default settings as described previously [22]. The maximum total blood volume processed was four times the patient's blood volume without an absolute limit. The collection time was restricted to a maximum of $5 \mathrm{~h}$ per LP session. As previously described, we used a predictive formula to calculate the necessary minimum blood volume to be processed $[23,24]$ and adjusted the collection time accordingly. An acid citrate dextrose (ACD) solution was used at an inlet:anticoagulant ratio of $12-15: 1$ at an inlet flow rate of $40-100 \mathrm{ml} / \mathrm{min}$. The maximum ACD infusion rate was set at $1.2 \mathrm{ml} / \mathrm{min} / \mathrm{l}$ total blood volume. The collection flow rate was set at $1 \mathrm{ml} / \mathrm{min}$ in case of the cMNC program. Continuous calcium gluconate infusion $(1 \mathrm{mmol} / \mathrm{h})$ was used to prevent citraterelated side effects. Daily LP sessions were continued until the collection goal was achieved, or additional LP sessions were considered unpromising due to low PB CD34+ cell counts and/or low quantities of CD34+ cells collected. The 
Table 1. Patient characteristics and previous therapy*

\begin{tabular}{|c|c|c|c|c|c|c|}
\hline Parameters & Overall & $\mathrm{MM}$ & $\mathrm{AL}$ amyloidosis & Lymphoma & Sarcoma & Germ cell tumor \\
\hline Patient number, n (\%) & $380(100)$ & $232(61)$ & $21(5)$ & $92(24)$ & $25(7)$ & $10(3)$ \\
\hline \multicolumn{7}{|l|}{ Gender, n (\%) } \\
\hline Male & $230(61)$ & $130(56)$ & $9(43)$ & $67(73)$ & $16(64)$ & $8(80)$ \\
\hline Female & $150(39)$ & $102(44)$ & $12(57)$ & $25(27)$ & $9(36)$ & $2(20)$ \\
\hline Age at PBSC collection, years & $57(13-59)$ & $61(38-79)$ & $58(39-68)$ & $55(19-72)$ & $27(13-58)$ & $40(23-49)$ \\
\hline Body weight at PBSC collection, $\mathrm{kg}$ & $76(47-136)$ & $77(49-123)$ & $79(52-96)$ & $77(52-136)$ & $66(47-97)$ & $75(56-115)$ \\
\hline $\begin{array}{l}\text { Disease duration until PBSC collection, } \\
\text { months }\end{array}$ & $5(1-187)$ & $5(3-145)$ & $6(1-187)$ & $7(2-128)$ & $4(2-105)$ & $8(1-24)$ \\
\hline \multirow[t]{7}{*}{ Specification diagnosis, $\mathrm{n}$} & & \multirow{7}{*}{\multicolumn{2}{|c|}{$\begin{array}{l}\text { MM } 231 \\
\text { POEMS } 1\end{array}$}} & DLBCL 37 & \multirow{7}{*}{$\begin{array}{l}\text { Ewing/PNET } 19 \\
\text { Other } 6\end{array}$} & \\
\hline & & & & FL 10 & & \\
\hline & & & & MCL 17 & & \\
\hline & & & & Burkitt 4 & & \\
\hline & & & & T-NHL 10 & & \\
\hline & & & & HL 13 & & \\
\hline & & & & other 1 & & \\
\hline \multicolumn{7}{|l|}{ Disease status, n (\%) } \\
\hline Newly diagnosed & $304(80)$ & $215(93)$ & $19(90)$ & $43(47)$ & $22(88)$ & $5(50)$ \\
\hline Relapsed/PD & $76(20)$ & $17(7)$ & $2(10)$ & $49(53)$ & $3(12)$ & $5(50)$ \\
\hline \multicolumn{7}{|l|}{ No. of therapy lines, $\mathrm{n}(\%)$} \\
\hline 1 & $304(80)$ & $215(93)$ & $19(90)$ & $43(47)$ & $22(88)$ & $5(50)$ \\
\hline 2 & $71(19)$ & $12(5)$ & $2(10)$ & $49(53)$ & $3(12)$ & $5(50)$ \\
\hline 3 & $4(1)$ & $4(2)$ & $0(0)$ & $0(0)$ & $0(0)$ & $0(0)$ \\
\hline 4 & $1(0)$ & $1(0)$ & $0(0)$ & $0(0)$ & $0(0)$ & $0(0)$ \\
\hline
\end{tabular}

minimum quantity of PBSCs for one transplant was $2 \times 10^{6} \mathrm{CD} 34+$ cells $/ \mathrm{kg}$ bw. Newly diagnosed MM (NDMM) patients less than 70 years of age were assigned a collection goal of three transplants; the collection goal in all other patients was one transplant.

For the analysis of the CD34+ cell collection result in relation to the patient's blood volume, a blood volume of $65 \mathrm{ml} / \mathrm{kg}$ in females and $75 \mathrm{ml} / \mathrm{kg}$ in males was assumed [25].

\section{Statistical Analyses}

Descriptive statistics and comparisons between subgroups were performed in R Studio (Version 0.99.451; R Studio, Inc. Boston, MA, USA). Data are presented as absolute numbers and percentages and, if not otherwise stated, as median and range.

To identify differences among subgroup means in PCBM, WBC, and absolute neutrophil counts (ANC) before mobilization, two-tailed Student's t-test or Mann-Whitney $U$ test (platelets) were performed. $\mathrm{p}<0.05$ was considered statistically significant.

To analyze the relationship between the PCBM and mobilization and collection outcomes (PB CD34+ cells/ $\mu$ l, collected CD34+ cells $\times 10^{6} / \mathrm{kg}$ bw, collected $\mathrm{CD} 34+$ cells $\times 10^{6} / \mathrm{kg}$ bw $/$ blood volume processed, and CD $34+$ cells $\times 10^{6} /$ fold patient's total blood volume processed), a linear regression approach was applied. The goodness-of-fit of the linear regression is provided by the coefficient of determination $\mathrm{R}^{2}$. $\mathrm{R}^{2} \geq 0.8$ was considered to indicate a relevant relationship. Relations between selected variables are visualized in scatter plots.

A receiver operating characteristic (ROC) [26] and optimal cut point analysis, including the cutoff determination, sensitivity, specificity, and positive and negative predictive value [27], was performed for the variables PCBM, ANC, and hemoglobin before mobilization with stratification by the need for plerixafor administration.

Logistic regression (binary logit model, Fisher's scoring optimization technique) was performed to estimate the impact of gender, age, PCBM, ANC, and hemoglobin before mobilization (independent variables) on the probability of plerixafor administration (yes/no, dependent variable). Due to missing ANC values, 90 observations were not included into the analysis. Overall 291 cases (n $=256$ without and $\mathrm{n}=35$ with plerixafor administration) were considered.

\section{Results}

\section{Patient Characteristics}

We included 232 (61\%) MM patients (215 (93\%) NDMM and 17 (7\%) relapsed MM (RMM)), 21 (5\%) AL amyloidosis patients, 92 (24\%) lymphoma patients, 25 (7\%) sarcoma patients, and 10 (3\%) germ cell tumor patients. In total, 7 of 17 RMM patients received high-dose melphalan and ABSCT as a previous line of therapy. The subgroup of lymphoma patients was heterogeneous, with diffuse large B-cell lymphoma (DLBCL, 37/92, 40\%) and mantle cell lymphoma (MCL, 17/92, 18\%) being the most frequent entities. 19 (51\%) patients with DLBCL had central nervous system in- 
Table 2. PBSC mobilization and collection ${ }^{\mathrm{a}}$

\begin{tabular}{|c|c|c|c|c|c|c|}
\hline Parameters & Overall & MM & AL amyloidosis & Lymphoma & Sarcoma & Germ cell tumor \\
\hline Patient number, n (\%) & $380(100)$ & $232(61)$ & $21(5)$ & $92(24)$ & $25(7)$ & $10(3)$ \\
\hline \multicolumn{7}{|l|}{ Blood count pre mobilization } \\
\hline $\mathrm{WBC} \times 10^{9} / 1$ & $6.4(0.6-81.4)$ & $5.7(1.7-56.9)$ & $6.9(3.1-13.5)$ & $8.5(0.6-39.0)$ & $9.7(1.9-81.4)$ & $6.4(3.4-9.5)$ \\
\hline $\mathrm{ANC} \times 10^{9} / 1^{*}$ & $4.2(0.3-51.2)$ & $4.0(0.5-51.2)$ & $5.0(1.1-8.7)$ & $4.9(0.3-13.3)$ & $4.5(0.9-14.5)$ & $3.6(1.5-6.6)$ \\
\hline Platelets $\times 10^{9} / 1$ & $241(11-759)$ & $241(11-633)$ & $250(113-480)$ & $249(15-759)$ & $141(37-611)$ & $253(120-530)$ \\
\hline Hemoglobin, g/dl & $11.5(6.0-15.6)$ & $11.9(7.4-15.6)$ & $12.8(6.0-14.6)$ & $11.0(8.0-15.6)$ & $9.9(6.7-11.9)$ & $11.4(9.2-12.3)$ \\
\hline \multicolumn{7}{|l|}{ Mobilization regimen } \\
\hline $\mathrm{CAD}$ & $218(57)$ & $211(91)$ & $7(33)$ & - & - & - \\
\hline $\mathrm{CD}$ & $10(3)$ & $1(<1)$ & $9(43)$ & - & - & - \\
\hline Cyclophosphamide & $10(3)$ & $8(3)$ & $1(5)$ & $1(1)$ & - & - \\
\hline CHOEP & $8(2)$ & - & - & $8(9)$ & - & - \\
\hline CHOP & $8(2)$ & - & - & $8(9)$ & - & - \\
\hline DHAP & $46(12)$ & - & - & $46(50)$ & - & - \\
\hline AraC/TT & $17(4)$ & - & - & $17(18)$ & - & - \\
\hline VIDE & $21(6)$ & - & - & - & $21(84)$ & - \\
\hline PEI & $6(2)$ & - & - & - & - & $6(60)$ \\
\hline Other chemomobilization & $12(3)$ & - & - & $6(7)$ & $3(12)$ & $3(30)$ \\
\hline G-CSF only & $19(5)$ & $12(5)$ & $4(19)$ & $1(1)$ & $1(4)$ & $1(10)$ \\
\hline \multicolumn{7}{|l|}{ PBSC collection setting, $\mathrm{n}(\%)$} \\
\hline Outpatient & $309(81)$ & $205(88)$ & $1(5)$ & $73(79)$ & $21(84)$ & $9(90)$ \\
\hline Inpatient & $71(19)$ & $27(12)$ & $20(95)$ & $19(21)$ & $4(16)$ & $1(10)$ \\
\hline \multicolumn{7}{|l|}{ Plerixafor administration, $\mathrm{n}(\%)$} \\
\hline Yes & $42(11)$ & $31(13)$ & $1(5)$ & $6(7)$ & $2(8)$ & $2(20)$ \\
\hline No & $338(89)$ & $201(87)$ & $20(95)$ & $86(93)$ & $23(92)$ & $8(80)$ \\
\hline \multicolumn{7}{|l|}{ PBSC collection } \\
\hline PB CD34+ cells/ $\mu \mathrm{l}$ at LP1 & $86(4-1,850)$ & $80(4-433)$ & $86(16-640)$ & $124(10-1,850)$ & $47(14-377)$ & $75(10-270)$ \\
\hline $\begin{array}{l}\text { PB CD34+ cells }>20 / \mu \mathrm{l} \text { at } \mathrm{LP} 1 \text {, } \\
\text { patient } \mathrm{n}(\%)\end{array}$ & $341(90)^{\#}$ & $208(90)^{\#}$ & $20(95)$ & $86(93)$ & $20(80)$ & $7(70)$ \\
\hline Number of LP sessions & $1(1-4)$ & $1(1-4)$ & $1(1-2)$ & $1(1-3)$ & $1(1-3)$ & $1(1-3)$ \\
\hline Overall processed blood volume, 1 & $18(5-70)$ & $19(10-70)$ & $15(5-42)$ & $13(5-52)$ & $19(8-50)$ & $20(11-61)$ \\
\hline Overall collected CD $34+$ cells $\times 10^{6} / \mathrm{kg}$ & $9.4(0.2-43.5)$ & $10.0(0.2-40.4)$ & $8.5(3.0-23.1)$ & $7.1(2.4-43.5)$ & $8.3(1.7-19.2)$ & $8.5(2.6-26.9)$ \\
\hline Overall collected CD $34+$ cells $\times 10^{6} / \mathrm{kg} / 1$ & $0.5(0.0-6.2)$ & $0.5(0.0-2.3)$ & $0.5(0.1-3.4)$ & $0.7(0.1-6.2)$ & $0.4(0.0-1.7)$ & $0.4(0.1-1.6)$ \\
\hline $\begin{array}{l}\text { Overall collected CD } 34+\text { cells } \times 10^{6} / \text { patients' } \\
\text { blood volume }\end{array}$ & $234(3-4,879)$ & $209(3-1,289)$ & $406(176-691)$ & $282(19-4,879)$ & $327(144-706)$ & $175(22-837)$ \\
\hline $\begin{array}{l}\text { Collection failure, }<2 \times 10^{6} \mathrm{CD} 34+\text { cells } / \mathrm{kg} \text {, } \\
\mathrm{n}(\%)\end{array}$ & $3(<1)$ & $2(<1)$ & $0(0)$ & $0(0)$ & $1(4)$ & $0(0)$ \\
\hline
\end{tabular}

${ }^{a}$ Unless otherwise indicated, data are given as median (range).

*ANC was available in 292 (228 multiple myeloma, 17 AL amyloidosis, 36 lymphoma, 6 sarcoma, 5 germ cell tumor patients) patients.

\#PB CD34+ cell number was not available in one multiple myeloma patient.

volvement. Approximately half of lymphoma patients had newly diagnosed (43/92, 47\%), the other half had relapsed disease (49/92, $53 \%)$. Patient characteristics are summarized in table 1.

\section{PBSC Mobilization and Collection}

Chemotherapy mobilization was performed in 361 (95\%) patients. 19 (5\%) patients were mobilized with G-CSF only. Plerixafor was administered in 42 patients $(11 \%)$ as a pre-emptive $(n=17)$ or rescue $(n=25)$ strategy. The frequency of plerixafor administration was highest in patients with RMM (5/17, 29\%) and lowest in patients with AL amyloidosis (1/20, 5\%). 29, 13 and 3 patients received one, two and three doses of plerixafor, respectively.
The median PB CD34+ level at day 1 of LP was $86 / \mu$ l (range $4-1,850 / \mu \mathrm{l}$ ) among all entities. Lymphoma patients had relatively high (median $124 / \mu \mathrm{l}$, range $10-1,850 / \mu \mathrm{l})$ and sarcoma patients relatively low (median $47 / \mu$ l, range $14-377 / \mu \mathrm{l}$ ) PB CD34+ levels. $90 \%$ of all patients but only $80 \%$ of sarcoma patients and $70 \%$ of germ cell tumor patients reached PB CD34+ levels $>20 / \mu \mathrm{l}$. The first dose of plerixafor was associated with a median 2.7 -fold increase in $\mathrm{PB}$ CD34+ levels (from a median of $12 / \mu \mathrm{l}$ to $33 / \mu \mathrm{l}$ ) and the second dose with a median 0.8 -fold change (from a median of $29 / \mu \mathrm{l}$ to $22.5 / \mu \mathrm{l}$ ). The median CD34+ collection result per kilogram bw in the entire patient population was $9.4 \times 10^{6}$ (range $0.2-43.5 \times 10^{6}$ ), with the highest median number of $10 \times 10^{6}$ in MM patients, whose collec- 
A

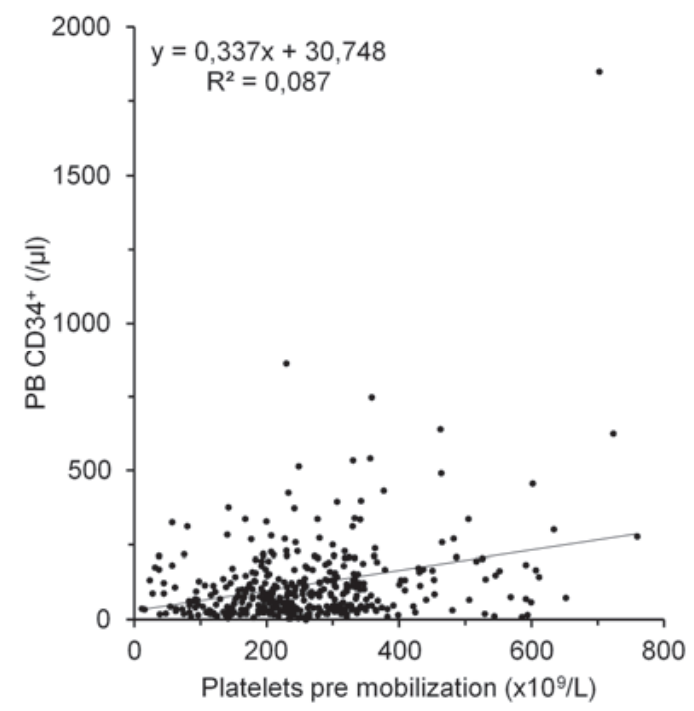

Fig. 1. Platelet counts before mobilization and mobilization/collection results. Data are presented for all patients. Each dot represents the mobilization or leukapheresis result of a single patient. PB CD34+ cell numbers (A), CD34+ cell collection results/kg bw (B), CD34+ cell collection results/kg bw/l blood volume processed $(\mathbf{C})$, and collected CD34+ cells $\times 10^{6} /$ fold patient's blood volume (bv) (D) are plotted (y-axis) against the premobilization platelet count (x-axis).
C

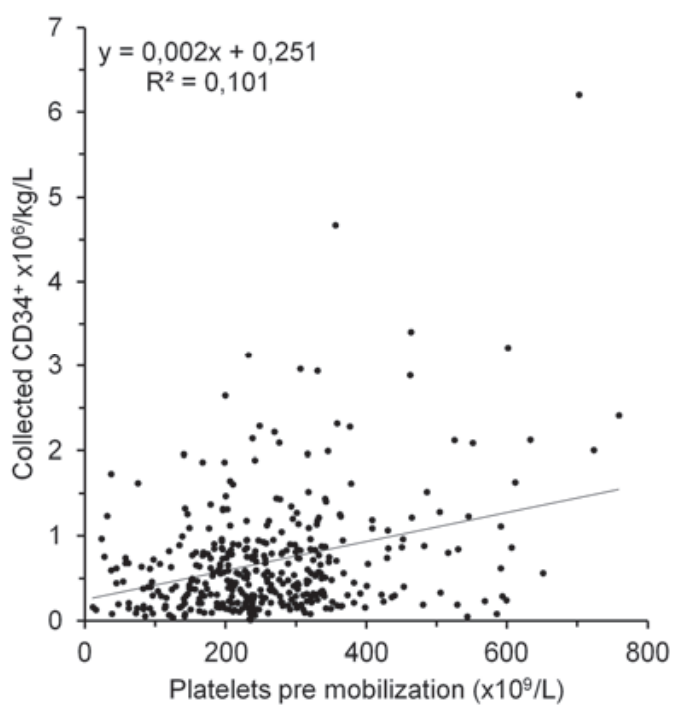

B

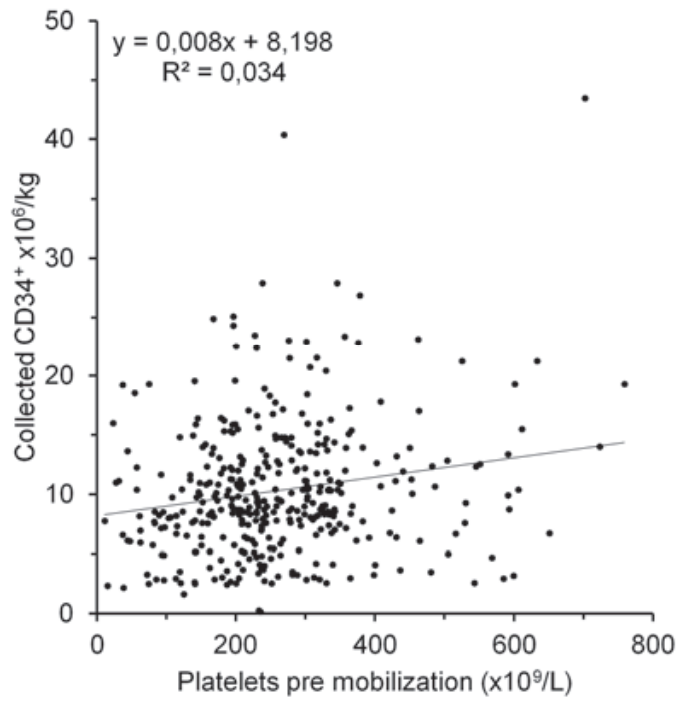

D

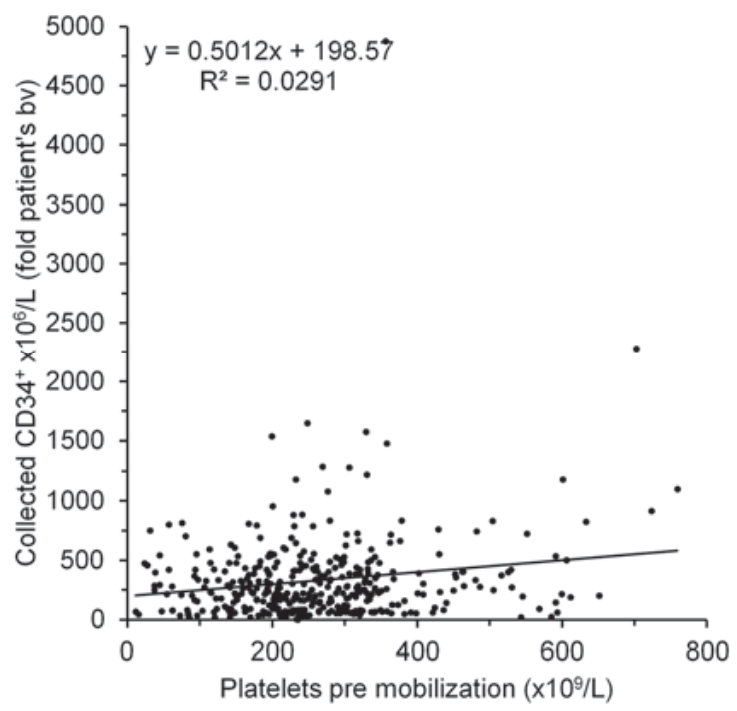

tion goal was three transplants in newly diagnosed patients. The minimum number of $2 \times 10^{6} \mathrm{CD} 34+$ cells/kg bw, representing one transplant, was achieved in 377 ( $>99 \%)$ patients. Collection failure at this threshold occurred in one patient each with NDMM, RMM or sarcoma. The median CD34+ cell number collected per kilogram bw per liter blood volume processed during LP in the whole patient population was 0.5 (range $0.0-6.2$ ) with similar values across disease subgroups. The median number of LP sessions performed was 1 (range 1-4). Mobilization regimens, blood counts before mobilization, and mobilization and collection results are detailed in table 2.

\section{Impact of Platelet Count before Mobilization on Mobilization and CD34+ Collection Result}

The median PCBM in the entire patient population was $241 / \mathrm{nl}$ (range 11-759/nl). PCBM was similar across disease subgroups, with the exception of sarcoma patients who had a lower median PCBM of $141 / \mathrm{nl}$ (range $37-611 / \mathrm{nl}$ ). To analyze the relation between the PCBM and mobilization outcome or CD34+ cell collection result, a linear regression analysis was performed. In the entire patient cohort, no relevant correlation was observed among the PCBM and the PB CD34+ cells/ $\mu \mathrm{l}\left(\mathrm{R}^{2}<0.1\right.$, fig. $\left.1 \mathrm{~A}\right)$, the collected CD34+ cells $\times 10^{6} / \mathrm{kg}$ bw $\left(\mathrm{R}^{2}<0.1\right.$, fig. $\left.1 \mathrm{~B}\right)$, the collected CD34+ cells $\times 10^{6} / \mathrm{kg}$ bw $/ 1$ blood volume processed $\left(\mathrm{R}^{2}<0.2\right.$, fig. $1 \mathrm{C}$ ), or the collected CD34+ cells $\times 10^{6} /$ fold patient's blood volume processed $\left(\mathrm{R}^{2}<0.1\right.$, fig. $\left.1 \mathrm{D}\right)$. Similarly, analyses in subgroups according to disease entities did not reveal significant results (data not shown). Patients with $\mathrm{PB} C D 34+$ cells $\leq 20 / \mu \mathrm{l}$ on day 1 of LP exhibited a significantly reduced hemoglobin level before mobilization compared with patients with PB CD34+ cells $>20 / \mu \mathrm{l}(10.9 \mathrm{~g} / \mathrm{dl}$ vs. $11.6 \mathrm{~g} / \mathrm{dl} ; \mathrm{p}=0.004)$. This was not the case for the PCBM ( $\mathrm{p}=0.464)$, the WBC $(\mathrm{p}=0.606)$, or the ANC ( $\mathrm{p}=$ 0.216 ) before mobilization. 
Fig. 2. ROC analysis and cutoffs for the need for pre-emptive/rescue plerixafor. A ROC and optimal cut point analysis was performed for PCBM, the ANC and the hemoglobin level before mobilization stratified by the need for plerixafor administration was performed. ' $x$ ' represents the position of the cutoff with the highest specificity (x-axis) and sensitivity ( $\mathrm{y}$-axis) for each variable.

Table 3. Impact of blood count parameters before mobilization, age and gender on the probability of plerixafor administration

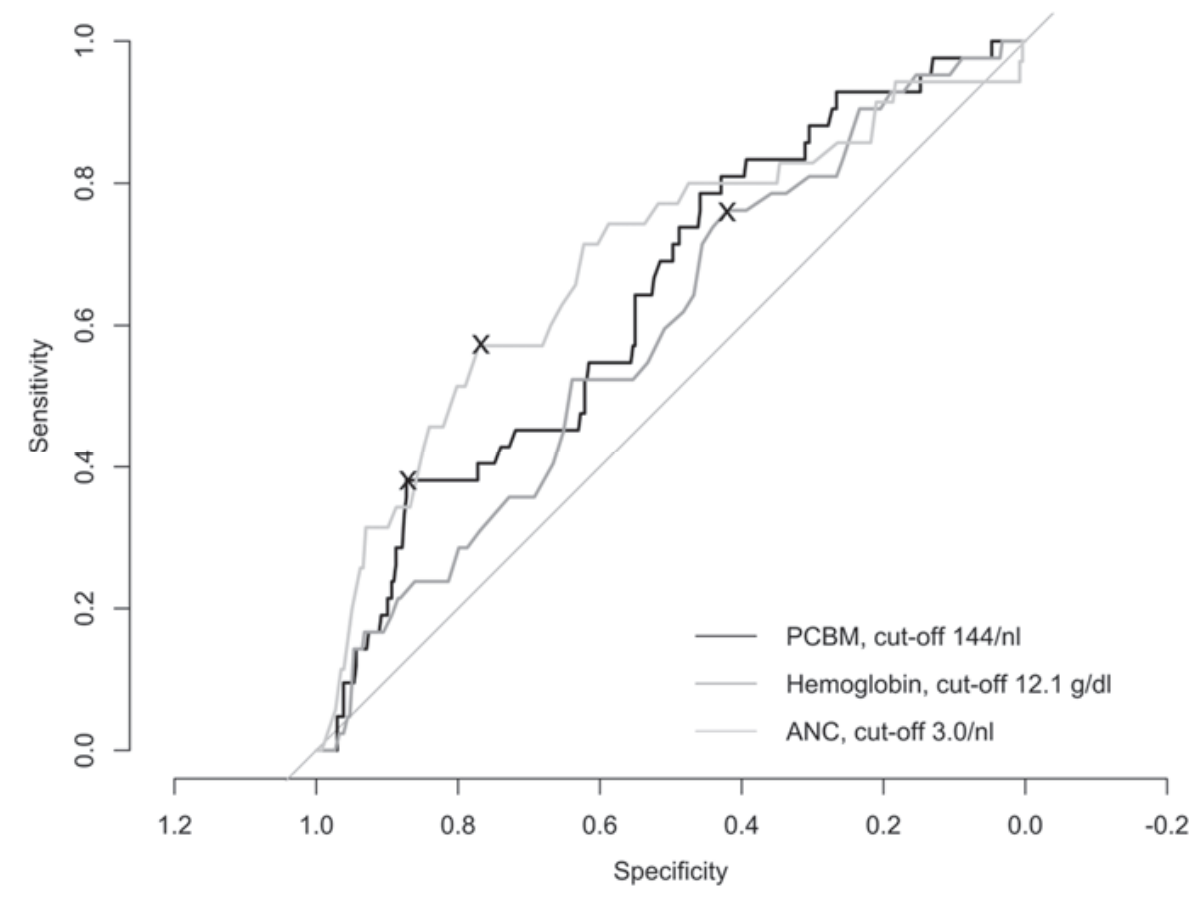

\begin{tabular}{|c|c|c|c|c|}
\hline \multirow[t]{2}{*}{ Independent variables } & \multicolumn{2}{|c|}{ Maximum likelihood } & \multicolumn{2}{|c|}{ Odds ratio } \\
\hline & estimate & $\mathrm{p}$ & estimate & $95 \%$ confidence limits \\
\hline ANC & -0.170 & 0.044 & 0.843 & $0.715-0.996$ \\
\hline PCBM & -0.006 & 0.003 & 0.994 & $0.989-0.998$ \\
\hline Hemoglobin & -0.172 & 0.148 & 0.842 & $0.668-1.063$ \\
\hline Gender & -0.348 & 0.074 & 0.498 & $0.232-1.070$ \\
\hline Age & 0.001 & 0.956 & 1.001 & $0.966-1.038$ \\
\hline
\end{tabular}

Logistic regression was performed to estimate the impact of gender, age, platelet count before mobilization (PCBM), absolute neutrophil count (ANC) and hemoglobin before mobilization on the probability of plerixafor administration. Overall $n=291$ ( $n=256$ without, $n=35$ with plerixafor).
Impact of Platelet Count before Mobilization on the Need for Pre-Emptive or Rescue Plerixafor

Patients receiving pre-emptive or rescue plerixafor had a significantly lower PCBM compared with patients collecting PBSCs without the addition of plerixafor $(217 / \mathrm{nl}$ vs. $245 / \mathrm{nl}$; $\mathrm{p}=0.003)$. The ANC (2.6/nl vs. $4.3 / \mathrm{nl} ; \mathrm{p}=0.048)$ and the hemoglobin level (11.0 $\mathrm{g} / \mathrm{dl}$ vs. $11.6 \mathrm{~g} / \mathrm{dl} ; \mathrm{p}=0.064$ ) before mobilization reached borderline significance, whereas the WBC before mobilization $(4.1 / \mathrm{nl}$ vs. $6.6 / \mathrm{nl} ; \mathrm{p}=0.188$ ) was not significantly different between patients with and without the need for pre-emptive or rescue plerixafor.

To identify a predictive cutoff for the need for pre-emptive/rescue plerixafor, a ROC and optimal cut point analysis was performed (fig. 2). As significant differences in these variables were identified in previously described subgroup analyses, the PCBM, the ANC, and the hemoglobin level before mobilization were considered. None of the cutoff levels identified for these variables was able to predict the need for pre-emptive/rescue plerixafor at a relevant sensitivity and specificity level: PCBM (cutoff 144/nl, sensitivity $38 \%$, specificity $87 \%$, PPV $8 \%$, NPV $73 \%$ ), ANC (cutoff $3.0 / \mathrm{nl}$, sensitivity $57 \%$, specificity $77 \%$, PPV 7\%, NPV 74\%), and hemo- globin level (cutoff $12.1 \mathrm{~g} / \mathrm{dl}$, sensitivity $76 \%$ specificity $42 \%$, PPV 7\%, NPV 86\%). Additional ROC models including a combination of two or three variables did not significantly improve the result (data not shown).

To estimate the impact of gender, age, PCBM, ANC, and hemoglobin before mobilization on the probability of plerixafor administration, a binary logistic regression analysis was performed (table 3). On multivariate analysis ANC and PCBM had a significant impact on the probability of plerixafor administration $\left(\mathrm{p}_{\mathrm{ANC}}=\right.$ 0.044; $\mathrm{p}_{\text {PCBM }}=0.003$ ). Higher ANC and PCBM before mobilization were associated with a lower probability of pre-emptive/rescue plerixafor administration (maximum likelihood estimate $_{\mathrm{ANC}}=$ -0.170 , odds ratio $_{\mathrm{ANC}}=0.843$; maximum likelihood estimate $\mathrm{PCBM}_{\mathrm{PC}}$ $=-0.006$, odds ratio $\left.{ }_{\mathrm{PCBM}}=0.994\right)$.

\section{Discussion}

In a previous study from our institution [10] dating back to the pre-plerixafor era, there was a negative correlation of the number 
of previous chemotherapy cycles and the capability of stem cell mobilization in patients with MM and lymphoma $(\mathrm{n}=840)$. We reported poor mobilization (peak CD34+ levels in $\mathrm{PB}<20 / \mu \mathrm{l}$ ) in $15 \%$ of patients and a failure rate of PBSC collection (threshold $2 \times$ $10^{6} \mathrm{CD} 34+$ cells $/ \mathrm{kg}$ bw) of $5 \%$ at the first mobilization attempt. This corresponds well with the $10 \%$ of patients with PB CD34+ cell levels $\leq 20 / \mu$ on day 1 of LP in the present study, which includes a plerixafor effect only in patients receiving pre-emptive plerixafor (i.e., starting on the evening before day 1 of LP) but not in patients with rescue plerixafor (i.e., starting after an insufficient LP session). With pre-emptive/rescue plerixafor, the collection failure rate was reduced to $0.8 \%$ in the present series, rendering the collection of at least a single transplant with a single mobilization attempt a realistic goal in all patients undergoing PBSC mobilization. Data from a prospective trial $(\mathrm{n}=102)$ [28] on pre-emptive/rescue plerixafor administration after chemotherapy mobilization demonstrated a reduced rate of poor mobilization (peak CD34+ cell levels in $\mathrm{PB}<20 / \mu \mathrm{l}$ ) of $3 \%$ versus $13 \%$ in a historical control group mobilized without plerixafor. Similarly, the rate of collection failure at a threshold of $2 \times 10^{6} \mathrm{CD} 34+$ cells $/ \mathrm{kg}$ bw was reduced from $21 \%$ to $4 \%$ with pre-emptive/rescue plerixafor. Two retrospective analyses $(n=166)$ [29] and $(n=159)$ [30] on pre-emptive/rescue plerixafor after steady-state mobilization (G-CSF) revealed collection failure rates of $8 \%$ and $5 \%$ (the latter one albeit at an adjusted threshold of $>2.5 \times 10^{6} \mathrm{CD} 34+$ cells/kg bw and $>5 \times 10^{6} \mathrm{CD} 34+$ cells/kg bw depending on the collection goal). Another retrospective analysis on pre-emptive plerixafor $(n=89)$ after mobilization with G-CSF resulted in a failure rate of $0 \%$ at $>2 \times 10^{6} \mathrm{CD} 34+$ cells/ $\mathrm{kg}$ bw. Therefore, our data compare favorably with the literature; however, due to the retrospective identification of patients at the stage of LP evaluation, it cannot be excluded that our failure rate would be slightly higher if patients undergoing mobilization but not reaching LP evaluation due to toxicity were included in the analysis. The number of these patients was not systematically assessed in the present patient cohort; however, from our experience we estimate it to a fraction of $<5 \%$ of all patients.

The PCBM has repeatedly been reported to be associated with mobilization and collection success/failure [12, 14-20]. Most of these analyses were performed in the pre-plerixafor era and/or did not incorporate plerixafor into the mobilization regimens. Therefore, considerable collection failure rates (13-29\%) were observed $[12,14,16,18-20]$. One analysis was performed in a setting of plerixafor addition to chemotherapy mobilization or steady-state mobilization in poor mobilizers; the collection failure rate was $30 \%$ [17]. Two analyses included only patients with RMM and prior HDCT/ABSCT $[12,15]$; it is more difficult to mobilize PBSCs due to impaired bone marrow reserve in these patients. Both analyses had collection failure rates of approximately $25 \%$ at the CD34+ cell levels used for correlation. Due to the low failure rate in our patient population, we were not able to investigate correlations of the PCBM with collection failure/success. However, our regression analyses of the PCBM and absolute numbers of CD34+ cells mobilized into PB or collected during LP did not reveal any relevant correlations. Due to the different collection goals for different pa- tient subgroups that potentially influenced the total CD34+ cell number collected, we calculated less goal-dependent measures of collection outcome by dividing the CD34+ collection result by the total blood volume processed (in liter) or the fold patient's total blood volume processed during collection. However, the PCBM did not correlate with these additional measures of collection outcome either.

Patients with PB CD34+ cells $\leq 20 / \mu$ have previously been defined as poor mobilizers [10]. We did not find significant differences in PCBM when comparing the subgroup of poor mobilizers ( $\mathrm{n}=38 ; 10 \%)$ with the remainder of the patient population in the present analysis. However, it should be noted that the day $1 \mathrm{~PB}$ CD34+ cell number already includes a plerixafor effect in patients not reaching $\mathrm{PB} C D 34+$ cells $\geq 10 / \mu \mathrm{l}$ with conventional mobilization and thus receiving pre-emptive plerixafor $(n=17)$. This limits comparability with previously published data on mobilization without plerixafor. Importantly, patients in need of pre-emptive/ rescue plerixafor had a significantly lower PCBM and ANC before mobilization on multivariate analysis. Thus, mobilization regimens with pre-emptive/rescue plerixafor appear to overcome the negative impact on PBSC mobilization/collection previously associated with a low PCBM. We identified a PCBM cutoff of 144 /nl by ROC analysis with regard to the probability of pre-emptive/rescue plerixafor administration. However, we were not able to develop a high sensitivity and/or specificity cutoff model when considering PCBM only or in combination with ANC and hemoglobin levels before mobilization.

Interestingly, we observed slightly but significantly lower hemoglobin levels before mobilization in poor mobilizers. There are only a few reports in the literature on the effect of the hemoglobin level before mobilization on mobilization/collection outcome. One group identified a hemoglobin level $<11 \mathrm{~g} / \mathrm{dl}$ before mobilization as a risk factor for collection failure in the univariate but not in the multivariate analysis [15]. Another group found that the hemoglobin level did not affect the collection outcome [14]. Despite the association with poor mobilizer status, hemoglobin levels were not associated with pre-emptive/rescue plerixafor administration in the present multivariate analysis.

A limitation of the present study is the fact, that only $5 \%$ of the patients were mobilized from steady state wit G-CSF only. Today, in a number of centers steady-state mobilization represents the standard procedure for MM patients. Future studies should therefore analyze systematically, if the findings of this study can be translated into this patient cohort.

In conclusion, mobilization of PBSCs with mobilization regimens incorporating pre-emptive/rescue plerixafor in the case of poor mobilization was efficient and allowed for collection of a minimum of $2 \times 10^{6} \mathrm{CD} 34+$ cells/kg bw required for a single transplant in nearly all patients ( $>99 \%)$. Mobilization regimens including pre-emptive/rescue plerixafor appear to overcome the negative impact on PBSC mobilization/collection previously associated with a low PCBM. Accordingly, a lower PCBM was significantly associated with the need for pre-emptive/rescue administration of plerixafor. 


\section{Acknowledgments}

We thank Renate Alexi, Erika Exenberger-Schiebel and Edgar Rieck-Wah for valuable help with data acquisition.

\section{Disclosure Statement}

The first author and all co-authors confirm that there are no potential conflicts of interest to disclose, except the following:
Marc-Andrea Baertsch: Travel grants from Amgen, BMS, Janssen, Novartis; Honoraria from Novartis.

Anthony D. Ho: Consultancy, honoraria and membership on Advisory Boards of Genzyme/Sanofi-Aventis.

Hartmut Goldschmidt: Research Support: Celgene, Janssen, Chugai, Novartis, BMS, Millennium; Advisory Boards: Janssen, Celgene, Novartis, Onyx, Amgen Takeda, BMS; Honoraria: Celgene, Janssen, Novartis, Chugai, Onyx, Millennium

Patrick Wuchter: Honoraria and membership on Advisory Boards of Sanofi-Aventis. Advisory Boards and Travel Grants from Hexal AG.

\section{References}

1 Cavo M, Rajkumar S V., Palumbo A, Moreau P, Orlowski R, Blade J, et al: International Myeloma Working Group consensus approach to the treatment of multiple myeloma patients who are candidates for autologous stem cell transplantation. Blood 2011;117: 6063-6073.

2 Cheah CY, Seymour JF, Wang ML: Mantle Cell Lymphoma. J Clin Oncol 2016;34:1256-1269.

3 Tilly H, Vitolo U, Walewski J, da Silva MG, Shpilberg $\mathrm{O}$, André $\mathrm{M}$, et al: Diffuse large B-cell lymphoma (DLBCL): ESMO clinical practice guidelines for diagnosis, treatment and follow-up. Ann Oncol 2012; 23(suppl 7):vii78-82.

4 Perales M-A, Ceberio I, Armand P, Burns LJ, Chen R, Cole PD, et al: Role of cytotoxic therapy with hematopoietic cell transplantation in the treatment of Hodgkin lymphoma: guidelines from the American Society for Blood and Marrow Transplantation. Biol Blood Marrow Transplant 2015;21:971-983.

5 Ljungman P, Urbano-Ispizua A, Cavazzana-Calvo M, Demirer T, Dini G, Einsele H, et al: Allogeneic and autologous transplantation for haematological diseases, solid tumours and immune disorders: definitions and current practice in Europe. Bone Marrow Transplant 2006;37:439-449.

6 Mohty M, Hübel K, Kröger N, Aljurf M, Apperley J, Basak GW, et al: Autologous haematopoietic stem cell mobilisation in multiple myeloma and lymphoma patients: a position statement from the European Group for Blood and Marrow Transplantation. Bone Marrow Transplant 2014;49:865-872.

7 Fruehauf S: Current clinical indications for plerixafor. Transfus Med Hemother 2013;40:246-250

8 Cheng J, Schmitt M, Wuchter P, Buss EC, WitzensHarig M, Neben K, et al: Plerixafor is effective given either preemptively or as a rescue strategy in poor stem cell mobilizing patients with multiple myeloma. Transfusion 2014;55:275-283.

9 Hundemer M, Engelhardt M, Bruckner T, Kraeker S, Schmitt A, Sauer S, et al: Rescue stem cell mobilization with plerixafor economizes leukapheresis in patients with multiple myeloma. J Clin Apher 2014;29:299304.

10 Wuchter P, Ran D, Bruckner T, Schmitt T, WitzensHarig M, Neben K, et al: Poor mobilization of hematopoietic stem cells-definitions, incidence, risk factors, and impact on outcome of autologous transplantation. Biol Blood Marrow Transplant 2010;16:490-499.
11 Giralt S, Stadtmauer EA, Harousseau JL, Palumbo A, Bensinger W, Comenzo RL, et al: International Myeloma Working Group (IMWG) consensus statement and guidelines regarding the current status of stem cell collection and high-dose therapy for multiple myeloma and the role of plerixafor (AMD 3100). Leukemia 2009;23:1904-1912.

12 Singhal S, Mehta J, Desikan K, Siegel D, Singh J, Munshi N, et al: Collection of peripheral blood stem cells after a preceding autograft: unfavorable effect of prior interferon-alpha therapy. Bone Marrow Transplant 1999;24:13-17.

13 Stiff P, Micallef I, McCarthy P, Magalhaes-Silverman $\mathrm{M}$, Weisdorf $\mathrm{D}$, Territo $\mathrm{M}$, et al: Treatment with plerixafor in non-Hodgkin's lymphoma and multiple myeloma patients to increase the number of peripheral blood stem cells when given a mobilizing regimen of G-CSF: implications for the heavily pretreated patient. Biol Blood Marrow Transplant 2009;15:249-256.

14 Sancho J-M, Morgades M, Grifols J-R, Juncà J, Guardia R, Vives S, et al: Predictive factors for poor peripheral blood stem cell mobilization and peak CD34(+) cell count to guide pre-emptive or immediate rescue mobilization. Cytotherapy 2012;14:823-829.

15 Papanikolaou X, Rosenbaum ER, Tyler LN, Sawyer J, Heuck CJ, Barlogie B, et al: Hematopoietic progenitor cell collection after autologous transplant for multiple myeloma: low platelet count predicts for poor collection and sole use of resulting graft enhances risk of myelodysplasia. Leukemia 2013;28:888-893.

16 Morris CL, Siegel E, Barlogie B, Cottler-Fox M, Lin P, Fassas A, et al: Mobilization of CD34+ cells in elderly patients ( $\geq 70$ years) with multiple myeloma: Influence of age, prior therapy, platelet count and mobilization regimen. Br J Haematol 2003;120:413-423.

17 Lanza F, Lemoli RM, Olivieri A, Laszlo D, Martino M, Specchia G, et al: Factors affecting successful mobilization with plerixafor: an Italian prospective survey in 215 patients with multiple myeloma and lymphoma. Transfusion 2014;54:331-339.

18 Mendrone A, Arrais CA, Saboya R, Chamone D de AF, Dulley FL: Factors affecting hematopoietic progenitor cell mobilization: an analysis of 307 patients. Transfus Apher Sci 2008;39:187-192.

19 Corso A, Caberlon S, Pagnucco G, Klersy C, Zappasodi $\mathrm{P}$, Alessandrino EP, et al: Blood stem cell collections in multiple myeloma: definition of a scoring system. Bone Marrow Transplant 2000;26:283-286.
20 Pozotrigo M, Adel N, Landau H, Lesokhin A, Lendvai $\mathrm{N}$, Chung DJ, et al: Factors impacting stem cell mobilization failure rate and efficiency in multiple myeloma in the era of novel therapies: experience at Memorial Sloan Kettering Cancer Center. Bone Marrow Transplant 2013;48:1033-1039.

21 World Medical Association Declaration of Helsinki: Recommendations guiding physicians in biomedical research involving human subjects. JAMA 1997;277: 925-926.

22 Lisenko K, Pavel P, Bruckner T, Puthenparambil J, Hundemer M, Schmitt A, et al: Comparison between intermittent and continuous spectra optia leukapheresis systems for autologous peripheral blood stem cell collection. J Clin Apher 2017;32:27-34.

23 Rosenbaum ER, O'connell B, Cottler-Fox M: Validation of a formula for predicting daily CD34+ cell collection by leukapheresis. Cytotherapy 2012;14:461-466.

24 Wuchter P, Hundemer M, Schmitt A, Witzens-Harig M, Pavel P, Hillengass J, et al: Performance assessment and benchmarking of autologous peripheral blood stem cell collection with two different apheresis devices. Transfus Med 2017;27:36-42.

25 Morgan GE Jr, Mikhail MS, Murray MJ: Clinical Anesthesiology, ed 3. New York, McGrawHill, 2001.

26 Robin X, Turck N, Hainard A, Tiberti N, Lisacek F, Sanchez J-C, et al: pROC: an open-source package for $\mathrm{R}$ and $\mathrm{S}+$ to analyze and compare ROC curves. BMC Bioinformatics 2011;12:77.

27 López-Ratón M, Rodríguez-Álvarez MX, Suárez CC Sampedro FG: OptimalCutpoints: An R Package for selecting optimal cutpoints in diagnostic tests. J Stat Softw 2014;61:1-36.

28 Milone G, Martino M, Spadaro A, Leotta S, Di Marco A, Scalzulli P, et al: Plerixafor on-demand combined with chemotherapy and granulocyte colony-stimulating factor: significant improvement in peripheral blood stem cells mobilization and harvest with no increase in costs. Br J Haematol 2014;164:113-123.

29 Chen AI, Bains T, Murray S, Knight R, Shoop K, Bubalo $\mathrm{J}$, et al: Clinical experience with a simple algorithm for plerixafor utilization in autologous stem cell mobilization. Bone Marrow Transplant 2012;47:1526-1529.

30 Abhyankar S, DeJarnette S, Aljitawi O, Ganguly S, Merkel D, McGuirk J: A risk-based approach to optimize autologous hematopoietic stem cell (HSC) collection with the use of plerixafor. Bone Marrow Transplant 2012;47:483-487. 